University of Louisville

ThinkIR: The University of Louisville's Institutional Repository

\title{
$5-2013$
}

\section{Identity crisis : the development of ethnic identities in South Africa and Northern Ireland and resolutions to ethnic violence.}

Erran Michael Huber

University of Louisville

Follow this and additional works at: https://ir.library.louisville.edu/honors

Part of the Political Science Commons

\section{Recommended Citation}

Huber, Erran Michael, "Identity crisis : the development of ethnic identities in South Africa and Northern Ireland and resolutions to ethnic violence." (2013). College of Arts \& Sciences Senior Honors Theses. Paper 50.

http://doi.org/10.18297/honors/50

This Senior Honors Thesis is brought to you for free and open access by the College of Arts \& Sciences at ThinkIR: The University of Louisville's Institutional Repository. It has been accepted for inclusion in College of Arts \& Sciences Senior Honors Theses by an authorized administrator of ThinkIR: The University of Louisville's Institutional Repository. This title appears here courtesy of the author, who has retained all other copyrights. For more information, please contact thinkir@louisville.edu. 
Identity Crisis: The Development of Ethnic Identities in South Africa and Northern Ireland and Resolutions to Ethnic Violence

\author{
By \\ Erran Michael Huber
}

Submitted in partial fulfillment of the requirements

For Graduation (summa or magna) cum laude

And

For Graduation with Honors from the Department of Political Science (if pertinent)

University of Louisville

May, 2013 
Ethnic conflicts in South Africa and Northern Ireland have long been characterizing features of those regions. During the Troubles and Apartheid, the ethnic tensions that had lingered for so long exploded into widespread violence in Northern Ireland, England and South Africa. The purpose of this paper is to characterize the presence of residual ethnic conflict in post-colonial states. ${ }^{1}$ In particular, this paper seeks to answer the question surrounding the reduction of ethnic violence in recent years, particularly following the signing of the Good Friday Agreement in Northern Ireland and the end of Apartheid in South Africa: why have levels of ethnic violence reduced over time in these states? Given that the issue of identity is the underlying factor in ethnic violence in both states, how can we account for an overall decline in violence when identities are still present?

There are similarities between the emergence of ethnic conflict in South Africa and Northern Ireland, in terms of social, political, and economic factors, and in the fact that these two states have both experienced a decline in overall ethnic violence. In particular, I assert that the development of ethnic identity, the concentration of power, social status, and economic tools primarily in the hands of one ethnic group, and the subsequent denial of progress for other ethnic groups sparked ethnic conflict in both states. However, the reasons behind a decline in ethnic violence are different in South Africa and Northern Ireland, despite the strong emphasis on identity that has served as an underlying cause of both conflicts. In South Africa, there is a remaking of identity, in particular among ethnically white South Africans, out of necessity of finding a new role in a multi-ethnic political system. In Northern Ireland, however, violence has

\footnotetext{
1 “"'With these caveats in mind, we define ethnic violence on first approximation as violence perpetrated across ethnic lines, in which at least one party is not a state (or a representative of a state), and in which the putative ethnic difference is coded--by perpetrators, targets, influential third parties, or analysts--as having been integral rather than incidental to the violence, that is, in which the violence is coded as having been meaningfully oriented in some way to the different ethnicity of the target." Roger Brubaker and David Laitin, "Ethnic and Nationalist Violence." Annual Review of Sociology 4 (1998): 423-452.
} 
been reduced not out of a redefinition of identity, but through a stalemate between ethnic groups created out of fear that a continuation of violence would evolve into an even bloodier conflict. Thus, while these states have established a tentative peace out from situations with similar causal factors and levels of violence, the means that they have used to accomplish these circumstances presents notable differences and ultimately, two various solutions to the issue of ethnic violence. With this in mind, this paper seeks to not only characterize the present state of affairs in Northern Ireland and South Africa, but also explore the factors behind what it will really take to truly put an end to the conflict. To do so, I first demonstrate that the issue of identity conflict was central to the development of ethnic tension in South Africa and Northern Ireland. Next, I outline the methods these states have used to reduce ethnic violence, which has occurred in spite of the continued presence of identity. Finally, I offer a variety of techniques to further maintain and preserve the relative peace that currently exists among ethnic groups.

I. Introduction: Identity Development and Ethnic Violence in South Africa and Northern Ireland

In his analysis of the origins of ethnic conflict, Michael Brown outlines the circumstances he believes are necessary for the development of internal conflict. He asserts that there are four factors that predispose a country to conflict: structural factors; political factors; economic/social factors; and cultural perceptual factors. ${ }^{2}$

\footnotetext{
${ }^{2}$ Michael Brown, "The Causes of Internal Conflict," in M. Brown (Ed.), Nationalism and Ethnic Conflict. (Cambridge, Massachusetts: MIT Press. 1997) pp. 3-25
} 
Table 1. Underlying Causes of Internal Conflict

Structural Factors

Weak states

Intra-state security concerns

Ethnic geography

Political Factors

Discriminatory political institutions

Exclusionary national ideologies

Inter-group politics

Elite politics
Economic/Social Factors

Economic problems

Discriminatory economic systems

Economic development and modernization

Cultural/Perceptual Factors

Patterns of cultural discrimination

Problematic group histories

Source: Michael Brown, “The Causes of Internal Conflict,” p. 5

He also asserts that internal conflicts are triggered through four ways: internal, mass-level factors

like bad domestic problems; external mass-level factors like bad neighborhoods; external, elite-

level factors like bad neighbors; and by internal, elite-level factors (bad leaders). ${ }^{3}$ However, the situations in Northern Ireland and South Africa call this model into question. Those circumstances demonstrate that it was the development of ethnic identity that was the underlying cause of ethnic tension and the adoption of a strong sense of superiority by the ruling class that guided and influenced the development of political, social, and economic institutions. While Brown asserts the four main clusters of factors are contributory to creating conflict, the problem with this argument is that cultural factors proceeds the implementation of discriminatory structural, political, economic institutions. Thus, I argue that these political, structural, and economic factors stem as a result of identity and culture, rather than cause culture-identity clashes. Rather than causes unto themselves, these factors become the tools that ethnic groups use against other enclaves to maintain the prosperity of the in-group. The inability of these groups to cooperate and the desire by these groups to retain or attain social, political, and economic dominance in an exclusive fashion is what causes ethnic conflict in these cases. Colin Knox and Rachel Monaghan support this assertion and wrote,

\footnotetext{
${ }^{3}$ Ibid.
} 
The theoretical basis for comparison...is that both countries exhibit fundamental differences over national identity or 'ethno-national' dimensions....Once the consciousness of being a part of an ethnic group is created then distinct languages, religious beliefs, and political institutions become part of that ethnicity. The fundamental conflict in Northern Ireland and South Africa is...between ethnic groups over national identity. $^{4}$

The subsequent exclusion of those deemed “Other” from social, political, and economic advancement through equal participation in these enterprises was the true trigger of ethnic conflict. Ethnocentrism and cultural jingoism pervaded the development of these identities, and political, social, and economic institutions were fashioned as a result of elites perpetuating these cultural myths. Thus, these factors were the result of trying to control ethnic groups, rather than the true root causes. As such, a more refined model is necessary to explain the history of ethnic conflict in South Africa and Northern Ireland, one that accounts for identity development and how this led to tensions among groups. In seeking to define a place in society, groups created unique identities around common ethnic characteristics, and barring the potential for advancement, members of these ethnic enclaves engaged in cultural myth-making, antagonism, and later the use of violence in an attempt to force a change in the status-quo more conducive to their ethnic group. ${ }^{5}$

In terms of structural factors, Brown identifies weak states as part of the composite features, and the issue of economic development and modernization compared to surrounding states as a part of economic factors. But it is difficult to see how these features contribute to the

\footnotetext{
${ }^{4}$ Colin Knox and Rachel Monaghan, Informal Justice in Divided Societies, (New York: Palgrave Macmillian. 2002). p.4

${ }^{5}$ Jack Snyder and Karen Ballantine, "Nationalism and the Marketplace of Ideas" in Nationalism and Ethnic Conflict, ed. Michael Brown, et al. (Cambridge: The MIT Press. 2001). pp. 62-64
} 
development of ethnic conflict in South Africa and Northern Ireland. In both cases, the United Kingdom established sound state institutions and a high rate of economic development as a result of its colonial presence in South Africa and Northern Ireland. ${ }^{6}$ In regards to the other underlying causes of internal conflict, an analysis of the circumstances in South Africa and Northern Ireland will demonstrate how these were not the original causes of ethnic conflict, but the result of identity development that asserted ethnic superiority.

\section{A. The Creation of British National Identity}

British national identity prior to the Troubles and Apartheid was rooted in a sense of cultural, political, and economic superiority and stimulated the development of symbolism, cultural myth-making and tension between all ethnic groups. An inherent view of superiority was embedded in British cultural self-evaluation, one that developed over time and found its apex during the 19th century, at the height of empire. As Robin Winks wrote,

If any one generalization may stand, however, it is that British imperialism was based upon a sense of superiority, upon a conviction of a superior economic system, a superior political code, on access to a superior view of some Higher Being, on a superior way of life. Idealists and realists alike sought to spread what they felt in their hearts was superior, to spread their institutions because they were superior and therefore not only easy to spread but a positive good for those to whom they were applied—or a positive way to preserve the power and prestige of England, itself worth preserving at all costs because superior. ${ }^{7}$

We see this sense of superiority permeate social, political, and economic institutions in a number of ways. New intellectual developments emerged that helped justify a sense of

\footnotetext{
${ }^{7}$ Robin Winks. British Imperialism: Gold, God, Glory. (New York: Holt, Rinehart and Winston. 1963). pp 2-3.
} 
superiority and rationalize the actions conducted under imperial rule, giving stronger credence to previously-held beliefs of primacy. Darwin's theory of natural selection, supplemented by the writings of Herbert Spencer, Thomas Malthus, and Francis Galton, would soon be applied to the human condition, and writers would posit that races that were more "civilized" were so as a result of favorable evolutionary conditions—-superiority as a natural and inherent quality. Such sentiments of Social Darwinism can be seen in the words of Joseph Chamberlain in his speech at the Imperial Institute in London in 1895. He states:

I was perhaps doubly worthy of this welcome, both for my faith in the Empire, and my faith in the English race. Yes, I believe in this race, the greatest governing race the world has ever seen, in this Anglo-Saxon race, so proud, tenacious, self-confident and determined, this race which neither climate nor change can degenerate, which will infallibly be the predominate force of future history and universal civilization...And I believe in the future of this world-wide Empire, of which no Englishman can speak without a feeling of enthusiasm. ${ }^{8}$

But Social Darwinism was not the only paradigm to emerge during this period that would change British social conceptions. Rudyard Kipling, the “...appointed songster, the poet laureate of Empire..."9 would capture national consciousness and help cement pro-imperialist mentalities in the masses. He not only advanced the growth of national empire, but also wrote of Britain's social place in the world, arguing that it was the "White Man's Burden” to bring the social, political, and economic glories of the British to the lesser races, "half-devil and half-child." Kipling tasked the British to bear a paternalistic responsibility toward the other peoples of the world, though they would resist and be unappreciative of the "gift." This mentality, while

\footnotetext{
${ }^{8}$ Victor Bérard. British Imperialism and Commercial Supremacy. (New York: H. Fertig. 1973). pp. 47-48.

${ }^{9}$ Ibid., p. 46
} 
probably intended to be "humanistic," nonetheless derived and reinforced the assumption of British social superiority.

Complementing the notions of British social superiority was the assertion that British rule was the best form of government for the people in its dependencies; thus the notion of superiority of political institutions becomes a part of British ethnic identity. Writing in 1858 in particular on India, but with reference to its other holdings, John Stuart Mill asserted:

There are two political functions devolving on the British nation. It has to provide for its own government; and for the government of the much more extensive and populous countries which are dependent on it. The majority however of its dependencies it has, wisely and necessarily, divested itself of the duty of governing; having found, after long trial, that it was unable to govern them satisfactorily. The only great outlying possession of the British Crown which is not now left substantially to its own government, is India.

The question is, in what manner Great Britain can best provide for the government, not of three or four millions of English colonists, but of 150 millions of Asiatics, who cannot be trusted to govern themselves. ${ }^{10}$

This example helps demonstrate not only the view that political dominance by the British ethnic group is the superior policy, but also simultaneously asserts the inferiority of other ethnic groups in self-management.

Further fueling the notions of ethnic superiority were the successes of Britain economically when compared to the rest of the world. The successes of the industrial revolution in Britain not only reinforced the notion of the British as the superior group, but created

\footnotetext{
10 John Stewart Mill, “A President in Council the Best Government for India” in The Collected Works of John Stuart Mill, XXX - Writings on India, ed. John M. Robson, Martin Moir, and Zawahir Moir (Toronto: University of Toronto Press, London: Routledge and Kegan Paul, 1990).
} 
circumstances that they believed necessitated the concentration of economic goods and services under their hand for continued success. The table below shows Britain's economic progress compared to its rivals:

Table 1.2 GDP per head, 1500-1820 (1990 international dollars)

\begin{tabular}{lrrrr}
\hline \hline \multicolumn{1}{c}{1500} & 1600 & 1700 & 1820 \\
\hline $\begin{array}{l}\text { most successful over the period } \\
\text { United Kingdom }\end{array}$ & 714 & 974 & 1250 & 1707 \\
moderately stuccessful over the period & 754 & 1368 & 2110 & 1821 \\
$\begin{array}{l}\text { Netherlands } \\
\text { Belgium }\end{array}$ & 875 & 976 & 1144 & 1319 \\
small advance over the period & & & & \\
Germany & 676 & 777 & 894 & 1058 \\
France & 727 & 841 & 986 & 1230 \\
Austria/Hungary & 585 & 677 & 780 & 927 \\
Poland & 462 & 516 & 566 & 636 \\
little change over the period & & & & \\
Italy & 1100 & 1100 & 1100 & 1117 \\
Spain & 698 & 900 & 900 & 1063 \\
\hline \hline
\end{tabular}

Source: Angus Maddison. The World Economy: A Millennial Perspective (Paris: OECD, 2006). p. 264.

This success in economic pursuits only served to enhance the notions of the British as a superior people when compared to their contemporaries.

The stress, therefore, must be placed on the sense of identity that leads to these other political, economic, and social factors, in particular the strong sense of superiority in the identity of the ruling class of Britons, which influenced the development of other ethnic ideologies.

\section{B. The Development of Identities and South African Ethnic Conflict}

\section{i. British Ethnocentrism and South African Development}

Complementing the notion of inherent superiority in the British identity was the idea that those outside the realm of Britishness had to conform to British norms or be excluded from opportunity. In South Africa, the British leveraged notions of superiority as justification to 
exclude other ethnic groups. ${ }^{11}$ A series of discriminatory political institutions began under the British, established to exclude non-Britons from enjoying economic or social equality as economic progress continued to rise. The adoption of British social and religious customs and the recognition that one's economic place was below that of the English were the hallmarks of a “civilized” Other. Failure to do so resulted in exclusion, and the development of tensions. ${ }^{12}$ As a result, the political affairs of South Africa became incorporated into to the common theme of superiority of Britishness and identity; it was from this belief that we see the institutionalization of discriminatory politics. William Worger and Rita Burns outline clearly the exclusionary practices that were a consequence of the expansion of British territory. They wrote:

In the new industrial cities, African workers were subjected to a bewildering array of discriminatory laws and practices, all enforced in order to keep workers cheap and pliable...In short, many of the discriminatory features so typical of twentieth-century South Africa—pass laws, urban ghettos, impoverished rural homelands, African migrant labour—were first established in the course of South Africa's industrial revolution. ${ }^{13}$

But native Dutch were left out of political power as well. They were seen as unable to properly govern on their own by the British in the country. As John Ridpath wrote at the time, "Hereupon Great Britain, seeing the inability of the Dutch to keep their grip on South Africa...sent a fleet to the cape and took possession of the country in the name of the Prince of

\footnotetext{
${ }^{11}$ The Dutch were seen as 'vulgar' and the African states as 'wretched;' "British settlers and travellers, of course believed themselves to be far better than their darker-skinned neighbours--including Dutch-speaking colonists--and, despite the inter-white conflict of the early years of British settlement, all were confident that their culture was incomparably superior to that of the other peoples of the region, Clifton Crais, White Supremacy and Black Resistance in Pre-Industrial South Africa: The Making of the Colonial Order in the Eastern Cape, 1770-1865. (Cambridge: Cambridge University Press, 1992). p. 128

${ }^{12}$ George Bennett. “The Concept of Empire, Burke to Attlee, 1774-1947,” quoted in British Imperialism: Gold, God, Glory ed. Robin Winks. (New York: Holt, Rinehart and Winston. 1963) p. 75

${ }^{13}$ William Worger and Rita Burms. South Africa : A Country Study (Washington DC: Federal Research Division, Library of Congress. 1996). p. 1
} 
Orange.” Believing the Dutch to be unable to govern themselves properly, the British summarily attempted to establish their authority over them. In this instance, we see the interplay of identity politics and the removal of a competing ethnic group from political power, fueling tensions between them.

Economic exclusionary practices leveraged by the British against other ethnic groups were common practice as well. The abolition of slavery came from the notion that slavery was not particularly beneficial to the British enterprise, and the decision to impose abolition in South Africa came as a result of the British ethnic group mandating this political development in its territories and forcing those living in them, including the Dutch, to conform to these standards. ${ }^{14}$ Farming was an integral part of the Dutch identity in South Africa; they called themselves the Boers, meaning farmers. Thus, the removal of the principal institution permitting them to farm-slave labor--was seen as an attack on their identity as a whole. As John Ridpath wrote at the time:

Slavery was not particularly advantageous to the British merchants and adventurers, governors and soldiers of the countires of the Cape, but it was the favorite institution of the Boers. The abolition fell upon them and disrupted their system. The Hottentots and Negroes whom the Boers had held in bondage escaped from their control. As a matter of fact, this was the first great measure which opened a fissure in the social and civil purposes of the Boers on the one side and the British on the other. ${ }^{15}$

From this example, we can see how ethnic tension stemmed from the imposition of one identity upon another: the British way would be the only way accepted, and the other ethnic groups

\footnotetext{
${ }^{14}$ John Clark Ridpath and Edward Sylvester Ellis. The Story of South Africa: An Account of the Historical Transformation of the Dark Continent by the European Powers and the Culminating Contest Between Great Britain and the South African Republic in the Transvaal War. (Chicago: C.W. Stanton Co., 1899). p. 62

${ }^{15}$ Ibid. p. $62-63$
} 
would need to conform to British ideals or be rejected. In many ways, this was the impetus of the series of treks the Dutch Boers would embark upon, hoping that an exodus from British-held territory would help them escape domination. But the abolition of slavery was only targeted against an institution perceived as barbaric, not in terms of an improved evaluation of the enslaved peoples themselves. Rather, a common perception of the landscape and shared social and economic goals among the Britons required the creation and maintenance of a dispossessed and dependent class. ${ }^{16}$ The creation of this class was the result of identity and ethnic considerations. ${ }^{17}$ Tensions would continue over the rights to gold and other precious metals in South Africa. These findings would dramatically alter the economic and political structure, as Clark and Worger wrote. They stated ““....the growing industry created ever-greater divisions between British and Boer, white and black, rich and poor. The British, seeking to secure as much of these resources as possible, conquered African states and established laws and economic policies that restricted the ability for Africans and Boers to reap the profits."

Driving these political and economic developments were a series of exclusionary national ideologies; identity development not only fostered the superiority of one's own ethnic group, but ipso facto, the lesser worth of others associated with a different identity. These stemmed from the notion that other ethnic groups were unable to manage affairs to the same degree; as John Hobson wrote:

The "occupation" of these new territories was comprised in the presence of a small minority of white men, officials, traders, and industrial organisers, exercising political an

\footnotetext{
${ }^{16}$ Clifton Crais, White Supremacy and Black Resistance, p. 129

${ }^{17}$ The development of agrarian capitalism and the struggle over land and labor is what initiated this perception, which centered on a series of dichotomies that fueled condemnation: "white" and "black," "civilization" and "barbarism," etc.-Ibid.

${ }^{18}$ Nancy L. Clark and William H. Worger, South Africa: The Rise and Fall of Apartheid, second ed. (Harlow, United Kingdom: Longman. 2011) p. 14
} 
economic sway over great hordes of population regarded as inferior an as incapable of exercising any considerable rights of self-government, in politics or industry. ${ }^{19}$

Because of the nature of their ethnic backgrounds, many Africans were subsequently excluded from advancement or a role in governing themselves under British rule. Exclusionary national ideologies strengthened against the ethnic Dutch following the conclusion of the Boer Wars. The British victory in the war brought new changes to the continent, but the themes of British superiority remained, and attempts to impose them were ramped up. The Boer republics were incorporated into the British Empire, and the appointment of Alfred Milner as governor of the newly acquired territories brought new attempts to Anglicize the territories. Milner sought to encourage further immigration of British citizens and believed that it was crucial to have a British majority among white male voters. ${ }^{20}$ Not only did he hope to secure a majority of British in the gold industry, but he also hoped to secure the local legislatures in favor of British interests through the power of numbers. In a strong example of the attempts of British imperialism to force the conformity of the Other. There were attempts at both denationalization and Anglicization in regard to Dutch-speakers. The use of Dutch was prevented in public schools and in courts of law, in the hope that they would be incorporated into a unified white and British identity rather than retain a separate identity. ${ }^{21}$

\section{ii. Afrikaner Cultural Identity Establishment}

In many ways, the development of Dutch Afrikaner identity stemmed from a result of and in response to British encroachment, and years of problematic group histories combined with an identity that infused notions of superiority within that identity. The Afrikaner version of history

\footnotetext{
${ }^{19}$ John Hobson. Imperialism. (London: G. Allen \& Unwin Ltd. 1938). p. 27

${ }^{20}$ Clark and Worger, South Africa, p. 17

21 “Building Apartheid’s Pillars,” The Christian Science Monitor, 11 June 1986
} 
that emerged during the nineteenth and twentieth centuries offered distinct views, tinged with cultural mythmaking and symbolic politics. These views "blossomed...among the Dutchspeaking settlers who perceived themselves as victims of British imperialism."22 As a result of interaction with the British, we see a distinct shift in identity away from the traditional rural farming identity—-the boers— to a new, more ethnocentric ideology.

Dutch attempts to establish their own identities and own context of social, political, and economic development in South Africa ran up against the conformity demanded of the British to their views and their inability to escape the encroaching British even through desperate attempts like the Great Trek sparked resentment and hostility. ${ }^{23}$ Through these experiences, we see the exploitation of these events in the context of cultural mythmaking and symbolic politics, two key features of the development of Afrikaner identity and ethnocentrism.

Two primary factors were central to the rise of Afrikaner prominence, and the decline of British influence following the establishment of the Union of South Africa: the establishment of their own views of superiority and the reclamation of an identity in the post-South African War era. In several ways, the Afrikaner self-conception mirrored the notions of superiority found in British imperialism, and the incompatibility of these world views was a primary contributor in the continuation of ethnic tensions between these groups and later, violence between whites and blacks after the Afrikaners attained place and power. A "unique" interpretation of the Bible through the Dutch Reformed Church was the primary foundation of these cultural values. Donald Akenson writes that most of the Afrikaners believed that South Africa had been put on

\footnotetext{
${ }^{22}$ Clark and Worger, South Africa, p.6.

23 "The Dutch farmers evidently supposed that this exodus and the establishment of a Republic in Natal would forever rid them of the domination of the British. But it was not to be so..."-Ridpath and Ellis, Story of South Africa, p. 63
} 
Earth by God in order to preserve a "line of divinely ordered historical development...that ran from the creation to the end of history."24

Combined with the notion held by most Afrikaners that their culture was one of the "pure bastions of western civilization," ${ }^{25}$ South Africa was supposed to be the safeguard of white civilization, a sentinel protecting three centuries of European development on the African continent. Thus, these Afrikaners, separating themselves from the remainder of the population, created economic institutions and political institutions inaccessible to outsiders. Through socializing institutions such as separate schools, Afrikaner cultural values were reinforced and passed on throughout the generations. In conjunction with this idea of superiority was the perception of outside threats to the culture, exacerbated by the British victory in the Boer War and the great masses of Blacks and Coloureds who also lived in the country. The fear of these forces only served to push the Afrikaners further into a mentality of isolation and protectionism.

Realization of these goals would prove more difficult. Segregationist policy implemented under British rule in the Union of South Africa did not benefit all whites equally. As Leonard Thompson wrote, "Although there were wealthy Afrikaners and poor British settlers, the ethnic division in the white population corresponded with occupational and class differences. Then, at the turn of the twentieth century the British government conquered the republics which the Afrikaners created in the interior and made a serious effort to denationalize the Afrikaners.” 26 After the war and the establishment of the Union, Afrikaners who had lost their land and economic stability in the war moved to the cities where the English had already dominated mining, banking, and commerce, and black Africans filled the unskilled labor positions. As they

\footnotetext{
${ }^{24}$ Donald Akenson, “The High Noon of Apartheid, 1948-1969,” in God's Peoples: Covenant and Land in South Africa, Israel and Ulster. (Ithaca, New York: Cornell University Press. 1992) p. 205

25 Ibid.

${ }^{26}$ Leonard Thompson. The Political Mythology of Apartheid. (New Haven: Yale University Press, 1985). p. 26
} 
continued to be shut out because of the pro-English sentiments of business and bureaucracy, the Afrikaners created a series of organizations like the Broderbund sought to mobilize members of their ethnic group and establish their own, separate institutions in order to secure social, political, and economic mobility and prominence away from the context of British society. ${ }^{27}$

The establishment of Apartheid and the subsequent ethnic conflict that stemmed as a result of the apex of Afrikaner prominence was a creeping process partially founded in Afrikaner desires for exclusivity and preeminence, not unlike those found in British identity creation and cultural mythmaking. The National Party stressed the proliferation of Afrikaans as a language, and several exclusive financial institutions were formed. Social organizations like The Broderbund were established to preserve Afrikaner culture. The promotion of cultural values based in ethnocentrism came to a head with the celebration of the centenary of the Great Trek; nationalist sentiment reached its apex at the celebration. During that time, at a gathering in Pretoria, there is the development of a strong movement that advocated nationalist sentiments and sought to appeal to all Afrikaners whatever their background. The sentiments of this gathering continued through the formation of the Ossewabrandagwag, an organization that sought to institute the rejection of participation in World War II, national unity, and develop an Afrikaner-controlled republic. ${ }^{28}$

Thus, a series of social and economic institutions that stemmed directly from the creation of this identity and codified many of the values of Afrikaner preeminence laid the foundation and the will for a more organized political movement to reshape society to fit with these values. The return of Liberals to power in Westminster and the rise of a new sense of Afrikanerdom

\footnotetext{
${ }^{27}$ Martin Schönteich and Henry Boshoff, "'Volk' Faith and Fatherland. The Security Threat Posed by the White Right", in Monograph. (Institute of Security Studies No. 81. 2003) pp.13-14

${ }^{28}$ Christoph Marx. “The Ossewabrandwag As a Mass Movement, 1939-1941” in Journal of Southern African Studies , Vol. 20, No. 2 (Jun., 1994), pp. 195-197
} 
combined at the beginning of the twentieth century to allow the Dutch their rise to power. With the granting of self-government in the Orange River Colony and the Transvaal, the creation of the Union of South Africa came into being primarily because of the shift in British mentality from securing British dominance to the maintenance of white supremacy overall in the face of a growing threat from non-whites demanding political power, social mobility, and greater economic opportunity. However, while the British and the Dutch agreed that the reduction of white power in general was undesirable and that cooperative steps should be taken to prevent it, this did not mean that tensions between the two European ethnic groups were greatly improved. The Afrikaners were the inheritors of the social, political, and economic structures that were the legacy of British dominance. ${ }^{29}$ To preserve the preeminence of white power, while at the same time seeking to prevent a loss of identity as was seen with the end of the Boer war, they sought to entrench themselves at the top while preserving enough rights and privileges for other whites to maintain support. Once the Dutch Afrikaners secured power at the end of the 1940s, they embarked on a "purification" scheme--one couched in the assertion of superiority of Afrikaner ethnic symbols and the dismantling of the other. We see the expression of ethnic identity and the response to violence and tensions between the British and the Dutch through the replacement of British sovereigns on postage stamps and money, the renaming of major honors, and the creation of new holidays. ${ }^{30}$ Even the national anthem was replaced with an Afrikaner one: Die Stem. Thus, there are similarities between Afrikaner policy toward other ethnic enclaves and that seen among the British, particularly after the Afrikaners take power--the preeminence of the ethnic group and the removal of those outside from power, sparking tensions and ethnic violence

\footnotetext{
${ }^{29}$ John Cell. The Highest Stage of White Supremacy: The Origins of Segregation in South Africa and the American South. (Cambridge: Cambridge University Press, 1982). p. 51

${ }^{30}$ Thompson, The Political Mythology of Apartheid, p. 40
} 
between the included and excluded peoples. The ethnic violence between the Boers and the British during the Boer Wars would not reemerge, but ethnic violence would reoccur in South Africa between the disenfranchised Blacks and Coloureds and the whites in power. As such, we can see the legacy of tension between identities, and how the Afrikaners sought to displace British identity and symbolism for their own once they attained power, a reflection of the tensions and violence between these two groups through their development. ${ }^{31}$

\section{iii. Black Cultural Identity Development}

The notions of a black identity, separate from that imposed upon this ethnic group by the white enclaves and defined in particular by its members, emerged under apartheid. This identity codified to better address problematic group histories and misconceptions perpetrated by centuries of subjugation and cultural mythmaking. Before this period, ethnic identity was fragmented into tribal enclaves, which allowed the British and Dutch to more easily divide the population. ${ }^{32}$ Both the Dutch and British engaged in patterns of cultural discrimination against the Africans. Leonard Thompson wrote that "Nearly all white South Africans, English-speakers as well as Afrikaners, assumed that any sensible, civilized person knew that Africans were a culturally inferior race and should be treated accordingly--an assumption that corresponded with the global distribution of power and wealth and was still endorsed by reputable Western scientists. „33 While there still remained tensions between the Dutch and the British, they were occasionally able to set aside their differences and combine their forces against the much larger African ethnic groups, engaging in inter-group and elite politics on temporary bases and finding common ground in their white, European ancestry in order to stave off the black ethnic

\footnotetext{
${ }^{31}$ Clark and Worger, South Africa, p. 32

32 Ike Rosamarin and Dee Rissik. South Africa. 2nd ed. (New York: Benchmark Books, 2003). p 59.

33 Thompson, The Political Mythology of Apartheid, p. 41
} 
conclaves. Despite their role in the fighting, Africans who expected that the end of the Boer wars would be followed by significant improvements in their economic and political situation went unrealized by either the peace treaty or Milner; that the exclusion came as a result of fear of a "native uprising" if improvements in the status of nonwhites occurred speaks to the continued view of non-Europeans as that of the lesser. ${ }^{34}$ As William Minter writes,

In the three decades from the foundation of the Union of South Africa to World War II, Britain increasingly shared that burden of political and economic leadership with the emergent ruling class of South Africa. Different factions contended for position, as lines were drawn between the spheres of influence of the South African state and the colonial powers, between London-based and South African-based capital, between the competing white "races" of Boer and Briton. Behind that variety, however, lay common ground. "Non-Europeans" were excluded from political rights as citizens, assigned instead to the role of anonymous streams of labor power. The more liberal and paternalistic versions of colonial ideology added at best a few qualifying clauses to this general premise. ${ }^{35}$

Patterns of discrimination emerged in which laws previously established by the British were taken to the extreme as Apartheid began to codify under the Dutch Afrikaners. Thus, black identity emerged as a result of the continued systematic exclusion from political, social, and economic development as a result of perceptions of superiority on the part of the whites, and the exclusion and denigration of nonconformists. Members of the black and coloured ethnic groups

\footnotetext{
${ }^{34}$ William Minter, King Solomon's Mines Revisited: Western Interests and the Burdened History of Southern Africa. (New York: Basic Books. 1988). pp. 37-38

${ }^{35}$ Ibid., p. 38
} 
began to adopt more cohesive notions of ethnic identity to act as a counterweight against the smaller, but more powerful, white groups.

The formation of a distinct, self-defined identity among Africans can be traced to the emergence of the Black Consciousness movement. Unlike the creation of identities and cultural myths rooted in superiority as seen with the British and Afrikaners, the creation of Black identity in South Africa was both reactionary and intentionally contrarian, intended to reframe historical events and conceptions of blackness in a different framework than that imposed upon this ethnic group by the more powerful white enclaves. ${ }^{36}$ As Leonard Thompson writes, two major circumstances created a generational shift in the demeanor toward whites from deference to defiance. The first came in 1960, with the massacre in Sharpeville and the subsequent banning of the African National Congress and the Pan-Africanist conflict, “with the result that their leaders came to the conclusion that they should abandon their reliance on nonviolent methods; armed struggle, the concluded was the only way to liberate their people from a regime that lived by violence. ${ }^{37}$ The second came as the result of an explosion in violence when African schoolchildren, who were protesting the compulsory use of Afrikaans in school, were fired upon by the police in Soweto, leading to hundreds of arrests, tortures, and killings. ${ }^{38}$

The aim of this ethnic group, therefore, was to remove what they viewed as suppression under white rule, and both attack and distance themselves from what they viewed as white values. This ultimately resulted in a strengthened mutual identity intended to challenge the ethnic enclaves of the Dutch and British for political, social, and economic superiority in South Africa

\footnotetext{
${ }^{36}$ Steve Biko. "The Definition of Black Consciousness" in I Write What I Like. (London: Bowerdean Press. 1978). pp.48-49

${ }^{37}$ Thompson, The Political Mythology of Apartheid, p. 192-193

${ }^{38}$ Ibid.
} 
as resistance to the imposition of Apartheid strengthened. ${ }^{39}$ In doing so, we see the reframing of historical events in a manner that stressed the grievances of the past ${ }^{40}$ and the development of symbolic politics that exploit that past. ${ }^{41}$ Thus, ethnic conflict in South Africa continued to be inflamed as this new identity was forged and clashed with the other enclaves for primacy.

Ethnic conflict between whites and non-whites emerged during this period because the nature of political, social, and economic order had changed. World War II and its conclusion had brought about significant changes: greater urbanization, economic opportunity through industrialization, and a new global concern with the struggle of oppressed peoples allowed the non-whites to organize in ways previously unattainable. While this caused the Afrikaner government to feel it needed to crack down hard to preserve its newfound political dominance, the seeds of change had been planted. The desire on the part of non-whites to attain improved political, economic, and social standing were fueled by the knowledge that these were things to which they were entitled as a part of "human rights," which strengthened their resolve in a profound way that would not have been possible in the centuries of repression and segregation that had existed before. ${ }^{42}$ It was the failure of the Afrikaner government to grant these rights and the extremities of Apartheid laws that sparked the ethnic conflict that would characterize the Apartheid period. However, it must not be forgotten that the tools and legacy for these laws were

\footnotetext{
39 "Nowadays, despite the separatist devices of the government, the Bantu speaking-Africans of the entire region are becoming more rather than less conscious of having a common identity, since they all experience the powerful impact of the South African state and the capitalist system and are drawn into similar conditions of wage labor and deprivation.” Ibid., p. 204

40 "We are merely forced by historic considerations to recognise the fact that we cannot plan side by side with people who participate in their exclusive pool of privileges, to make sure that both priviliges are shared. We don’t believe--we don't have faith in them anymore that they are willing to share with us without any form of...” --From Steve Biko’s evidence in his trial, Steve Biko. “The Righteousness of Our Strength” in I Write What I Like. (London: Bowerdean Press. 1978). p. 123

41 ...Group fears and myths that justified hostility were strong, leading to powerfully hostile mass attitudes. These attitudes created a context for leaders in which predatory policy was more popular than moderate policy; and the hostile narratives provided a symbolic vocabulary that the leaders used as tools to mobilize support.--Stuart Kaufman. "Symbolic Politics or Rational Choice? Testing Theories of Extreme Ethnic Violence.” (International Security, Volume 30 Issue 4. 2006). p. 48.

${ }^{42}$ Sue Williamson, Resistance Art in South Africa (Cape Town: David Phillip Publishers, 1989). p. 70
} 
already in place, and the mentalities that justified them, came as a result of the social, political, and economic conditions that had come to define British rule in South Africa.

What can we take away, therefore, from this historical overview of South Africa before the eruption of ethnic tension during Apartheid? The exclusion from power, social standing, and economic opportunities on the basis of non-Britishness by the encroaching empire lead to the development of grievances and cultural myth-making among all ethnic groups, sparked desires for change, and we see the creeping rise of increased violence to effect change or retain power. Ethnic conflict, therefore, stemmed from the desire of competing ethnic groups to wrest authority and control from the dominant power in charge and reformat society to be more beneficial to their specific ethnic group. When these goals were countered, tensions became bloodshed. When the Afrikaners took power after the British, and began to implement an even more extreme version of exclusion, tensions between all groups came to a head, and the ethnic violence between whites and blacks that had been brewing for centuries began to boil over. All of these factors, however, were the result of the creation of defined ethnic identities and the infusion of ethnocentrism within them.

C. The Influence of Ethnocentric Identities and Development of Ethnic Tension in Northern Ireland

\section{i. British Ethnocentrism in Ireland}

Tension between the British and the Irish had its origins in the first arrivals of Englishmen in the sixteenth century, where the seizure of large tracts of land and concentrated economic and political resources in the hands of this ethnic enclave, and political representation and social mobility became restricted. When the English began serious colonization in 1550, their increased expansion sparked tensions as the Irish became further displaced. Until 1603, 
the British and the Irish in Northern Ireland were largely separated, with the English concentrated in the south and a thriving Celtic culture in the Ulster region. While there was a concerted effort and the partial anglicizing of the rest of the Irish, Ulster remained a stronghold under Celtic princes with a Celtic society. ${ }^{43}$ In 1603, however, the last Celtic Prince, Hugh O’Neill surrendered to Lord Mountjoy, the English Lord Deputy of Ireland. As Donald Akenson writes, "This event marked a watershed in Irish history: the last of the independent Irish princes was subdued...England could now settle matters in Ireland permanently, or so it seemed." 44 As a result, there is a concerted displacement of Irish identity on the island. As Donald Akenson writes, "Most of the Irish chiefs were pardoned and allowed to keep their lands, but they, like Tyrone and Tyrconnell, were granted the land not as Irish chiefs but under new rules that converted them into English style landlords; the superseding of the Irish system of land tenure by the English system rapidly undercut the Celtic social system."45 This action reflects the continuing theme of the issue of ethnic superiority in the ruling power and the attempts to convert or subdue the Other.

An acceleration of the displacement of identity and the tension between the Irish and the English over the issue of identity would be seen with the departure of over a hundred Irish chiefs seeking to escape the decline of their influence and the harassment of the English government, which left Ulster without native Irish leadership and open to further English manipulation. To fill this power vacuum, the British engaged in the plantation of Ulster, bringing in British authorities and concentrating social, economic, and political power in the hands of the British. As for the

\footnotetext{
${ }^{43}$ Donald Akenson, "The Covenantal Culture of the Ulster-Scots," in God's Peoples: Covenant and Land in South Africa, Israel and Ulster. (Ithaca, New York: Cornell University Press. 1992) p. 103

${ }^{44}$ Ibid.

${ }^{45}$ Ibid., p. 105
} 
Irish natives, only a small amount of land was granted to them, in exchange for certain loyalty and the adoption of English social and agricultural customs. As a result of these changes, the native Irish went from owning almost all of the land and living according to their own customs and traditions before 1603 to the lowest tenants, holding the least amount of land and the poorest tracts. ${ }^{46}$ Their political leaders had left, and the majority social systems fell, leaving only their Catholic traditions to hold on to. Thus, for the Irish, their sense of identity was either displaced or overwritten by the incoming British, and this loss of identity was perpetuated as the result of the British ethnic enclaves utilizing the political, economic, and social tools available to them to secure their own place in power. Violence thus erupted from the tensions between these ethic groups as dispossessed Catholics protested against their new status, sparking several civil wars between the Irish and the British. These early conflicts, particularly the victory of the British in the Battle of the Boyne, would come to be an integral part of cultural mythmaking and symbolic politics as ethnic conflict would continue through the twentieth century. After this victory, British regimes would further exclude the Irish from what little political power they retained and rescind a series of other rights, isolating them from the spoils enjoyed by the British ethnic enclave. ${ }^{47}$

Thus, from the beginnings of British encroachment in Ireland we can see how the issue of identity fueled the use of political, social, and economic tools to exclude the other or force conformity. Through 1691, the Irish had been ruled a minority group of Protestant English, who passed a series of laws which discriminated against the Irish Catholic population and nonAnglican protestants and which lasted up through the beginnings of the nineteenth century. These Penal Laws were targeted against the Other, to force the Irish, who had clung to religion

\footnotetext{
${ }^{46}$ Ibid. p. 107

${ }^{47}$ Charles Tilly, The Politics of Collective Violence, (New York: Colombia University Press. 2003). p. 112
} 
as the last vestige of their culture, and other non-Anglicans to accept British ethnic norms, discriminating against those who would threaten the primacy of Britishness. ${ }^{48}$ These penal laws excluded non-Anglicans from economic, political, educational and social opportunities, almost a precursor to the way Black and Coloured Africans were excluded in South Africa. As Tilly writes, "In Ulster, a triangular relationship emerged: Anglican landlords dominated politics and economic life; leaseholders, skilled workers, and professionals came mainly from the Protestant population; and Catholics concentrated disproportionately in landless labor." ${ }^{49}$ Thus, the notions of superiority of British identity created discriminatory political institutions as Ireland entered the eighteenth century, which were exacerbated further as the British began to outnumber the Irish in Ulster.

Through the nineteenth century, past instances of British conquest and displacement of the Irish were justified through intellectual assertions of a superior culture. As Brian Jenkins writes,

More common was the disdainful and casual dismissal of Ireland's Catholics as “an inferior and degraded caste.” One Catholic Irishman who had embraced Britishness protested that "the spirit of eminence and masterdom" was "so fixedly settled" in the English that they could never bring themselves to regard the Irish as their equals. ${ }^{50}$

In the previous centuries of British rule in Ireland we see the precursors of this development through evidence of attempts to maintain economic superiority, political power, and social prominence for adherents to British institutions, primarily through religious discrimination. As the British began to develop a stronger national identity, so too were the

\footnotetext{
48 The Treaty of Limerick, 1691

49 Tilly, The Politics of Collective Violence, p. 112

${ }^{50}$ Brian Jenkins, Irish Nationalism and the British State: From Repeal to Revolutionary Nationalism. (Quebec: McGill-Queen’s University Press. 2006). pp. 49-50
} 
concentrations of these elements into the hands of the British in Ireland strengthened. As British identity was refined through intellectual developments, this ethnic enclave sought to further distinguish themselves from the Irish, and thus both justify and expand British control over Irish social, political, and economic institutions. This is similar to the justifications used in South Africa to remove the opportunities of advancement from the Boers and non-whites. As Paul Rich wrote,

The Irish were often a particular object of professional interest with the measurement and recording of different racial types, particularly those of 'Saxon' and 'Celt.' This has led some scholars...to argue that the Victorian conception of Irish racial make-up reflected an underlying anthropological racism that was similar in content to colonial racism toward black and brown peoples. ${ }^{51}$

Thus we see the further relegation of the Irish to lower social castes on the basis of pseudoscientific and perceived immutable differences between them and the British. But this view of the Other as lesser that was a defining characteristic of British imperialism also had political ramifications as well. Rich wrote:

Curtis has also seen the obsession with the racial difference of the Celtic Irish explaining the continued resistance to demands for Home Rule in the decades before 1914. The racial stereotyping of the Irish was in effect a basic pillar of the Unionist claim that the Celtic Irish were essentially unfit for self-government and required continued direct rule from the Anglo Saxon government in London. ${ }^{52}$

\footnotetext{
${ }^{51}$ Paul Rich, "Social Darwinism, Anthropology and English Perspectives of the Irish, 1867-1900," in History of European Ideas. (Volume 9, Issues 4-6. 1994). p. 777.

${ }^{52}$ Ibid.
} 
Exacerbating the notion of separate identities and fueling conflict between them was the creation of political-religious organizations. The Orange Order for British and Ribbonmen for the Irish have helped contribute to division through the use of symbolic imagery and political rhetoric that emphasizes ethnic differences, different cultural conceptions of historical events, and the roles their ethnic enclaves played in those events. These organizations often stage public challenges and shows of strength, which become violent as they stir the opposing group to action, ${ }^{53}$ creating and proliferating problematic group histories. As Niall O’Dowd wrote,

The 12th may well have been a celebration of a long ago battle at the Boyne in 1690, but it came to symbolize for generations of Catholics the "croppie lie down" mentality on the Orange side. The thunderous beat of the huge drums was just a small way of instilling fear into the Nationalist communities, while the insistence on marching wherever they liked through Nationalist neighborhoods was also a statement of supremacy and contempt for the feelings of the other community.

In terms of economic concerns, there is evidence of the proliferation of British economic interests over that of Ireland to such a degree that it has even been pointed to as a contributing factor in the development of the Irish Potato Famine. James Froude wrote at the time: "England governed Ireland for what she deemed her own interest, making her calculations on the gross balance of her trade ledgers, and leaving moral obligations aside, as if right and wrong had been blotted out of the statute book of the Universe."54

Thus, we see how the developments in British self-conception came into play during the nineteenth century, and how the exclusion of the non-British from equal access created social,

\footnotetext{
53 Tilly, The Politics of Collective Violence, p. 113

${ }^{54}$ Quoted in Seamus MacManus. The Story of the Irish Race: A Popular History of Ireland(4th rev. ed.). (New York: Devin-Adair Co. 1944.) p.
} 
political and economic tensions, much as they did in South Africa. As it did during the civil wars. ethnic violence would emerge as the Irish began to resist the continued state of mistreatment directed against them, and counter the notions of British identity as the highest level of human condition.

\section{ii. Irish Consciousness and the Development of Ethnic Tensions}

The creation of an Irish identity in response to the creation of a British identity emerged in a manner similar to the creation of a Black identity in South Africa: within the context of redefining ethnic ties on the basis of in-group qualifications, rather than those imposed by British superiority and distinctions. Irish nationalism began to codify during the $19^{\text {th }}$ century, seeking to foster a commitment to Irish culture as distinct from the British. The Celtic Revival movement, stemming from the development of the Society of the United Irishmen and the Young Irelanders, among other groups were based on the "the indivisibility of Gaelic cultural integrity, territorial sovereignty, and the interlinking of Gaelic identity with profession of the Roman Catholic faith." ${ }^{55}$ But this was not simply a movement that sought simply a revival; it was couched in opposition to British treatment of Irish Culture. Writing in 1892, Charles Duffy stated:

A group of young men, among the most generous and disinterested in our annals, were busy digging up the buried relics of our history, to enlighten the present by a knowledge of the past, setting up on their pedestals anew the overthrown statues of Irish worthies, assailing wrongs which under long impunity had become unquestioned and even venerable, and warming as with strong wine the heart of the people, by songs of valour

\footnotetext{
${ }^{55}$ David A. Valone and Jill Marie Bradbury. Anglo-Irish Identities 1571-1845. (Lewisburg: Bucknell University Press. 2008). p. 39.
} 
and hope; and happily not standing isolated in their pious work, but encouraged and sustained by just such an army of students and sympathizers as I see here to-day. ${ }^{56}$

From this attempt to redefine Irish identity, we see the same notions of ethnocentrism and superiority of the in-group in relation to the Other emerge. As Alan O’Day observes, this notion was exemplified through the development of symbolism; "Several 'superior' national symbols, such as the harp, the colour green, St Patrick’s Day, and the shamrock, retained their significance in the Free State..."57 Thus, the notions of superior identity became evident through the replacement of the symbols of British rule with ones this ethnic group perceived as more fitting.

Irish resistance to British rule and resentment of unequal treatment had been a common theme, but it took the alterations of the existing global paradigm for the suppressed people to begin to mount a counteroffense. Much as World War II provided a series of global political, social, and economic changes that allowed the non-whites to organize and mobilize against discriminatory laws that ensured white supremacy and the exclusion of the Other, near the beginning of the nineteenth century, the success of the American Revolution and the French Revolution gave heart to the Irish, and they launched a rebellion in 1798 against English rule. While the rebellion was not successful, it started a movement against the current status of social, political, and economic exclusion that would continue, and added new narratives to the well of cultural mythmaking and symbolic politics that the Irish would recount in their justification of further resistance and bloodshed against a people whom they viewed as having repressed them for centuries.

\footnotetext{
${ }^{56}$ Gregory Castle. Modernism and the Celtic Revival. (Cambridge: Cambridge University Press, 2001.) p. 239 ${ }^{57}$ Alan O’Day. Reactions to Irish Nationalism. (London: Hambledon Press, 1987). p 19.
} 
Ironically, it was the granting of greater rights and freedoms to the Irish that exacerbated, rather than ameliorated, ethnic tensions between the British and the Irish. As Tilly writes,

As the franchise expanded and party politics began to flourish, election campaigns became new sites of Protestant-Catholic rivalry and also new occasions for collective violence. Mass mobilization of anti-British movements across Ireland as a whole during the later nineteenth century drew in many Ulster Catholics, thus spurring Unionists (as the pro-British Protestant forces began to call themselves) to self-defense. On both sides, arming, drilling, and threatening accelerated into World War I, when Irish nationalists took up arms and declared a republic--only to suffer another round of deep depression. ${ }^{58}$

The British, however, were not able to provide the means for social, economic, and political advancement quickly enough to satisfice the demands of the Irish, nor to ameliorate centuries of ethnic tension stemming from discrimination against the Irish. Thus, the granting of increased rights resulted in violent attempts to fully break the power of the government and replace it with self-rule, as was seen in South Africa.

The failure of the Home Rule Act to appease either Unionists or Nationalists sparked several attempts by the Irish to overthrow the British government and subsequent resistance by the British against these attempts. While most of Ireland gained independence from Britain, the areas with the greatest concentration of British, the Six Counties of Ulster, remained under control of the Crown. Attempts by the Irish to incorporate these territories into a United Ireland and resistance by British nationalists kept the continuation of ethnic conflict until the signing of the Belfast agreement.

\footnotetext{
${ }^{58}$ Tilly, The Politics of Collective Violence, p. 114
} 
In Ulster, the Catholics began to unify in protest against British exclusionary practices leveled against them. Civil rights groups like the Campaign for Social Justice and the Northern Ireland Civil Rights Association emerged in hopes to counteract the Irish position as a lesser ethnic group under the law. ${ }^{59}$

\section{The Application of Ethnic Violence Solution Theory to South Africa and Northern Ireland}

We have established that it was tension stemming from competing identities that were the true underlying causes of ethnic conflict in South Africa and Northern Ireland. These identities still remain today, even though violence has subsided. How, then can we explain the continued presence of ethnic identities in conjunction with the reduced presence of violence in these states? The application of theoretical factors can help explain how this is possible, and help highlight the differences in approaches to lessening violence taken by South Africa and Northern Ireland.

In Northern Ireland, there is a prevailing view among scholars that the bulk of the violence is for the most part over; the security dilemma has been resolved, the paramilitary groups have lain down their arms, and rational negotiation has won the day. As Alan Aughey writes, “There has been a tentative consensus amongst students of Northern Ireland politics that the Belfast Agreement of 10 April 1998 may be taken to mark the end of a particular era...popularly known as 'the Troubles' or 'the recent Troubles' in order to distinguish them from the political violence

\footnotetext{
59 Daniel Wigmore-Shepherd, "Ethnic Identity, Political Identity and Ethnic Conflict: Simulating the Effect of Congruence Between the Two Identities on Ethnic Violence and Conflict," in Structure and Dynamics: eJournal of Anthropological and Related Sciences, 5(3). (2012): 4
} 
which attended the partition of Ireland in the early 1920s.” 60 This consensus is exemplified by J.C. Beckett, who writes:

Though the settlement left a legacy of bitterness, issuing occasionally in local and sporadic disturbances, it inaugurated for Ireland a longer period of general tranquility than she had known since the first half of the eighteenth century. ${ }^{61}$

Scholars have even chosen to characterize the state of Northern Ireland following the Good Friday Agreement as having shifted substantially enough to warrant reclassification; the ethnic conflict has ended not because of a formal pronouncement of such, but because of a shift from a violent state of affairs to political conflict between parties. Analysis of the history of the conflict given by Jesse and Williams demonstrates this conclusion. They write that The Good Friday Agreement in Northern Ireland signaled a new approach to solving the intractable conflict,"62 and go on to characterize the conflict in terms of political parties and the stalemates of assemblies, rather than as an ethnic issue; they highlight the importance of a “...changed political landscape in Northern Ireland." ${ }^{63}$ Additional writings pointing to the cease-fire agreement component and its subsequent follow-through by the IRA as indicative of the end of this conflict. According to A.A. Barros D’Sa “Perhaps the quarter century of futile terrorism and internecine strife in Northern Ireland is coming to an end... The cease fire has generated a mixture of relief, scepticism and hope.” 64

\footnotetext{
${ }^{60}$ Alan Aughey. The Politics of Northern Ireland: Beyond the Belfast Agreement. (2nd ed.) (London, England: Routledge. 2005). pp. 7-8

61 J.C. Beckett(1966) The Making of Modern Ireland 1603-1923. (London, England: Faber and Faber.1966) p. 461

${ }^{62}$ N. G. Jesse \& K.P Williams. Ethnic Conflict: A Systematic Approach to Cases of Conflict. (Washington, DC: CQ Press. 2011) p. 98

63 Ibid. 100

${ }^{64}$ A. A. B. Barrows D'Sa. “Twenty Five Years of Vascular Trauma in Northern Ireland.” (British Medical Journal, Volume 310, Issue 1. 1995) Retrieved from http://www.ncbi.nlm.nih.gov/pmc/articles/PMC2548428/
} 
In Northern Ireland, ethnic violence has subsided as a result of the use of deterrence. ${ }^{65}$ There is an unstable peace in the region as a result of the decision of both sides to come to a tentative settlement through the decommissioning of weapons and normalization of security as outlined in the Good Friday Agreement. ${ }^{66}$ The threat of ongoing terrorism and a fear of further violence forced a political accommodation which addressed some of the continuing political tensions over the status of Northern Ireland. The combination of a strong outside power administering the state in conjunction with this deterrence has effectively reduced violence from the level of bombings and shootings to the occasional riot.

The conditions of tentative peace in South Africa, however, have emerged from different circumstances. In Northern Ireland, the violence was concluded through political development; ethnic identities have largely remained intact, which results in lingering tensions between ethnic groups. In South Africa, violence has been addressed less through political means but through social reformation. Much in the way elites mobilized identity instrumentally during the Apartheid years, there has also been a movement in the post-Apartheid years to redefine identity and one's place in South African society. ${ }^{67}$ Through attempts the resolution of grievances and a concerted effort in the state to reorganize around a single South African identity, violence in South Africa has subsided through attempts to reform ethnic identity conceptions, particularly

\footnotetext{
65 "Mutual deterrence does not guarantee that there will be no further violence, but it reduces the probability of outbreaks, as well as the likely aims and intensity of those that do occur."--Chaim Kaufman. "Possible and Impossible Solutions to Ethnic Conflict.” In M. Brown (Ed.), Nationalism and Ethnic Conflict. (Cambridge, Massachusetts: MIT Press. 1997) p. 458

${ }^{66}$ Agreement Reached in the Multi-Party Negotiations, 10 April 1998

67 "Two phenomena, both almost uniformly overlooked in the current climate of utter condemnation, bolster such a perspective. The first is a largely impressionistic observation for which there is scant statistical, but much anecdotal, support: A surprising amount of personal goodwill and understanding exists among the races in South Africa, and it should survive anything short of the most cataclysmic political upheaval.[1] There is a recognition, by all save the more extreme elements, of the necessity for racial accommodation. The whites understand that black aspirations will have to be met in some form; blacks in turn understand that the whites are in South Africa to stay and that they will make an essential contribution to any post-transitional society.”--Peter Spiro, “Better Now Than Never: Economic and Social Reforms In South Africa’ in Cato Policy Analysis No. 81(Washington D.C.: Cato Institute. 1987).
} 
through education and the notion of shared values. ${ }^{68}$ Much as ethnic identities in South Africa emulated British superiority complexes, they could also emulate the British retreat from superiority and empire as was seen after the conclusion of the Second World War.

Thus, even though identity formation and the ethnocentrism that became a defining feature of those identities was the underlying cause in ethnic conflict in South Africa and Northern Ireland, the two states have approached the issue with different solutions; in the former, concerted efforts at reshaping identity have emerged, and in the latter, efforts to separate and promote tolerance of ethnic identities, rather than reshape them into something new, have been the focus.

As such, we see the implementation of two competing theories regarding the resolution of ethnic conflict, both with success at curbing ethnic violence. In Northern Ireland, the state has implemented the political solution offered by Chaim Kafuman. In "Possible and Impossible Solutions to Ethnic Civil Wars," Chaim Kaufman argues that the only viable solution to ethnic conflict is when the opposing groups are demographically separated into defensible enclaves, or with the presence of international forces or a conquering empire to keep the peace. ${ }^{69}$

In Northern Ireland the application of this notion has been attempted in official and unofficial political capacities both before the Troubles and during. As a result of the Anglo-Irish Treaty to end the Irish War of Independence, Northern Ireland was given the opportunity to opt out of joining the new Irish Free State in the south as part of a dominion, or remaining a part of the United Kingdom. With a Protestant majority, six of the nine counties of Ulster elected to remain

\footnotetext{
${ }^{68}$ Currently, however, education is seen as a weapon of transformation. The Revised National Curriculum Statement (RNCS) sees education as a tool that could root the South African values enshrined in the Constitution. Democracy, social justice, non-racism, equality and reconciliation are among the fundamental values of the South African education system --Vuyisile Msila, "From Apartheid Education to the Revised National Curriculum Statement: Pedagogy for Identity Formation and Nation Building in South Africa” in Nordic Journal of African Studies 16(2) (2007): 146-160.

${ }^{69}$ Chaim Kaufman. "Possible and Impossible Solutions to Ethnic Conflict.” In M. Brown (Ed.), Nationalism and Ethnic Conflict. (Cambridge, Massachusetts: MIT Press. 1997) pp. 444-484
} 
part of the new United Kingdom of Great Britain and Northern Ireland. Thus, part of Kaufman's theory was exercised; the country was split into Protestant and Catholic parts. The theory was also applied within Northern Ireland itself. Public housing is overwhelmingly segregated, especially in the capital of Belfast. As a result of the Troubles, and persistent ethnic tensions both before and after this period, once-mixed areas have been replaced by overwhelmingly polarized neighborhoods. This is the result of not only public housing developments, but an overwhelming amount of self-segregation among the people themselves. In 2004, it was estimated that $92.5 \%$ of public housing in Northern Ireland was divided along religious lines, with the figure rising to $98 \%$ in Belfast. ${ }^{70}$. In conjunction with this, the government has erected a series of "peace lines," high walls and gates across the roads designed to curtail violence by preventing travel at certain points of tension and in an effort to keep interface zones--areas where Protestant and Catholic neighborhoods intersect--more safe. Additionally, we see the political validity of the presence of both ethnic identities, with the extension of equal rights for all citizens and even the option for citizens to choose which passport they wish to acquire—an Irish or a British—in line with their identities. Further, we see not only the continued presence of British rule to clamp down on violence, but the combined opportunities for involvement with the Republic of Ireland, allowing for peace enforcement through international presences as well as a powerful, conquering state.

In South Africa, however, there has been a different approach to curbing violence, one outlined by Stuart Kaufman. Stuart Kaufman argues that both peace and reconciliation are necessary for lasting stability and the amelioration of hostile emotions, and writes that "a comprehensive strategy integrating the logic and practice of reconciliation initiatives with the traditional tools of international mediation and conflict resolution," is the "new hypothesis" to

\footnotetext{
70 “Self-imposed Apartheid.” The Guardian, 22 July 2007. Retrieved from http://www.guardian.co.uk/society/2004/apr/14/northernireland.societyhousing
} 
resolving longstanding ethnic conflict issues. ${ }^{71}$ The components of this strategy involve mutual recognition and acceptance, invested interests and goals in developing peaceful relations, as well as fully normalized, cooperative political, economic and cultural relations. Recognition initiatives as a part of this strategy can include reconciliation initiatives, verbal or symbolic acknowledgement of past deeds, NGO-organized problem-solving workshops, cultural events, media initiatives, and educational reform. Public truthtelling, partial justice, redefinition of social identities, and a call for a new relationship between parties. The approach in South Africa has been more focused on creating lasing peace through social transformation utilizing these aspects. Public truthtelling and partial justice to ameliorate tensions between groups for past misdeeds and facilitate forward progress have been seen in the development of the Truth and Reconciliation Commission. ${ }^{72}$ Political leaders and ethnic elites emphasized the need for a new relationship between ethnic enclaves in the aftermath of Apartheid.` Perhaps most crucially, several symbolic steps have been taken to redefine South Africa as one united nation with many parts, and the state and elites have undertaken a concerted effort to redefine social identities into a greater, more cohesive conception, stepping away from the traditional ethnocentric notions of superiority and toward greater inclusion. ${ }^{73}$ While the traditional ethnic identities still remain in South Africa, there is still a concerted effort at altering self-conception that is not seen strongly in Northern Ireland; promotions of a combined Ulster identity do not compare to the efforts seen in South Africa to create a "rainbow nation." Thus, while both Northern Ireland and South Africa

\footnotetext{
${ }^{71}$ Stuart Kaufman. "Escaping the Symbolic Politics Trap: Reconciliation Initiatives and Conflict Resolution in Ethnic Wars.” in Journal of Peace Research, 43(2) (2006): pp. 201-218.

72 Truth and Reconciliation Commission of South Africa Report, Volume 1

73 'Identity formation as well as the myth of the 'rainbow nation' and its performative intention have served to discursively create a national identity that has been top-down in its constitution and implementation.”-Nahala Valiji, Creating the Nation: The Rise of Violent Xenophobia in the New South Africa (Unpublished Masters Thesis: York University Centre for the Study of Violence and Reconciliation, 2003).
} 
have seen a decline in the level of ethnic violence, the South African approach has been more effective in helping to resolve ethnic tensions between on the whole. ${ }^{74}$

III. The Remnants of Ethnic Identities-Lingering Problems and the Potential for Further Violence

Ethnic violence has been consistently low in both South Africa and Northern Ireland. However, the consistent presence of ethnic identities in these states still presents a problem. Despite the best efforts of elites, racism and ethnic identities have not been completely eliminated from South Africa, and they continue to hold a prominent place in Northern Ireland society. Thus, there is the potential for ethnic violence to resurge. To prevent this, three primary factors currently preventing progress must be targeted and suppressed before the potential for a resurgence of violence can be further repressed: the trickle-down of hostile ideology, the element of youthful mischief-making and the presence of spoilers.

The first initiative in creating a new paradigm should be the prevention of the assumption of hateful ideology by the next generations. The perpetuation of cultural mythmaking must not be allowed to poison the youth growing up in Northern Ireland; and South Africa; failure to do so will only result in the perpetuation of the conflict. Public and personal initiatives can assist in this regard. The importance of parents imparting values based not on hatred, but on cooperation, tolerance, and acceptance, cannot be overstated. Holidays with charged cultural elements must be retooled to be inclusive or eliminated. Illustrating the problem, in Northern Ireland with the continuation of such "traditions" as the burning of large wooden pillars composed of shipping crates and pallets and decked with flags, jerseys, scarves and other memorabilia representing the Republic of Ireland by Protestants in "celebration” of the anniversary of the Battle of the Boyne,

74 "Northern Ireland Reconciliation Plan Arouses Anger." The New York Times. 28 January 2009. 
combined with such sectarian chanting as "Fuck the Pope and the IRA!" and inflammatory paramilitary songs and parades, it's no wonder that ethnic divisions are not only perpetuated by the adults, but adopted by their children. In South Africa, the use of inflammatory songs by politicians like Julius Malema ${ }^{75}$ and the symbolic exploitation of instances like the murder of the far-right Eugene Terreblanche ${ }^{76}$ serve similar purposes. These practices must stop in order for peace to go forward. In Northern Ireland, a fully-funded and comprehensive Truth and Reconciliation Commission, modeled on that of South Africa, will allow for the realities of the conflict to be better displayed in full public view, providing humanizing elements to the consequences of perpetual antagonism, but this commission must be allowed to bring responsible parties to trial for their actions or risk the perception of ineffectiveness. In South Africa, which has already conducted a truth commission, active steps need to be taken to hold perpetrators of atrocities on all sides responsible for their actions and brought to justice. Further, the nature of murals in Northern Ireland and public symbols recalling the Apartheid years must be replaced. These prominent displays are an important factor in the perpetuation of cultural mythmaking, and should instead reflect a character of inclusion, togetherness, and the elements of harmony. As well, workshops and informal discussions will help not only the youth to reject the perpetuation of hatred and intolerance, but adults as well. Kaufman writes:

The aim of such workshops is to bring together people from opposing sides of a conflict, so they can replace their mythical beliefs about the other side with better information and replace their hostility and fear with enough understanding to make a compromise peace look attractive and attainable. If successful, these experiences start to build trust among participants across group lines. 'Track II diplomacy', in particular, involves problem

\footnotetext{
75 “Malema Charged Over 'Kill the Boer'”, news24, 10 March 2010

76 “Tensions Rise at Terreblanche Hearing,” ReutersVideo, 6 April 2010
} 
solving workshops carried out by elites who have access to top leaders but are not part of the official leadership. Such talks allow for an informal, and often more creative, exploration of options than formal leaders are willing to risk. ${ }^{77}$

These elements thus empower those in society with a peace mentality to spread this ideology to others. As well, some of these major elements, such as workshops and truth commissions, can be conducted by third-parties, thus allowing them to go forward even in the event of opposition of top leaders fearful of losing their base of power if the elements of conflict disappear.

Second, the exploitation of the conflict and perceived past grievances by troublemaking youth as a flimsy excuse to cause violence, with some perception of justification or cultural impunity must be counteracted. During my time in Belfast, I witnessed several riots and uprisings coinciding with July 11-12, the anniversary of the Battle of the Boyne. In making inquiries, a large consensus of those whom I spoke with on both the Protestant and Catholic sides see the conflict as ancillary to these actions. Rioters with petrol bombs blowing up cars in the streets are not doing so out of real protest against grave injustice, but because the appearance of doing so allows them to behave disruptively without the fear of tangible consequences. In reality, it is violence for the sake of violence. Similarly, in South Africa, violence continues to be perpetrated against white farmers, and more than 3000 have been killed since 1994, and numerous protests and riots, most notably in 2008, stemming from xenophobia and ethnic tensions. In addition, as Terrence Corrigan writes,

Persistent crime resulted in many people turning to vigilantism. South Africa is no longer threatened by violent instability, but insecurity arises from other types of violence: gang activity, urban terrorism, vigilantism, and feuding in the taxi industry...It suggests a

\footnotetext{
${ }^{77}$ Stuart Kaufman, “Escaping the Symbolic Politics Trap,” p. 201-218.
} 
level of organisation, is perceived to target certain people or groups systematically (unlike random crime) and can become a 'way of life' for both victims and perpetrators. ${ }^{78}$

Such elements are alluded to by John Mueller, where he argues that ethnic conflict is the perpetrations of small, roving bands of thugs, asserts that ethnic motivations were ancillary for these gangs, and that the primary motivations of the thugs stem solely from the opportunity to perpetrate what he calls "Carnivals of often-drunk looting, destruction and violence,"79 with relative impunity and with the blessings of authorities. These "ruffians," as Mueller calls them, see their exercises not as removing the stain of an enemy people, but as the chance to bully, intimidate and indulge freely in the base whims of the id. However, unlike Mueller, who states in his article that because of these localized expressions of violence, ethnic conflict does not exist, I argue the opposite; by choosing to frame their actions in the context of ethnicity and injustice perpetuated from one ethnic group to another, they contribute to the overall culture of ethnic tensions, and thus help continue the framing of conflict in ethnic terms--hence the proper application of the label "ethnic conflict." In addressing this repeated and problematic issue, it becomes necessary to redefine the perception of these thugs. They argue that they are fighting against an ethnic injustice; it must therefore be counter-argued in the press and among cooperative elements in society, both publicly and privately, that they are not. As well, the police must take a harder stance on these youth. Instead of setting up stationary riot lines and blasting the rioters with water cannons, there must be tangible and visible crackdowns on this kind of behavior, more numerous arrests, as well as a greater intolerance and condemnation of this kind of disruptive behavior in public statements. Only the reframing of these youth in the proper context--that of people taking advantage and exploiting the true horrors of the past for their own

\footnotetext{
78،"Violence Gnaws at South Africa’s Security Blanket,” Weekly Mail and Guardian, 22 March 2001

79 John Mueller. “The Banality of Ethnic Conflict.” International Security. 25(1) (2005): p. 45.
} 
pleasure--will allow for the necessary public shaming and condemnation, which combined with increased police action will help curb this element.

Finally, the remnants of spoilers and their hostile feelings must be attended to. In Northern Ireland, radical sectarian elements are still attempting to use violence in order to attain victory for their side. On April 28, 2012, a 600-pound van containing a bomb with the potential to kill everyone within a 50-meter radius was intercepted at the border between Northern Ireland and the Republic of Ireland. ${ }^{80}$ In addition, a small car bomb was also detected and defused. Had these bombs reached their intended target, it could have inflamed ethnic tensions once again. Steven McCaffery further reports that "Dissident republicans opposed to the peace process are being blamed for the failed attack." ${ }^{81}$ Returning again to the murder of Eugene Terreblanche in South Africa, widespread fears of the resurgence of political violence as a result of the trial of his attackers were present, and while these did not come to fruition, they underly the continuing ethnic tension between groups. ${ }^{82}$ These action and others similar to it represent the still-present elements of spoilers, those looking to derail the peace process for their own aims. Again, a stronger police and judicial crackdown on these elements, combined with a public shaming, will help mitigate these spoilers. Once these three factors have been implemented, the cultures of Northern Ireland and South Africa should be significantly more conducive to a return to a sense of cooperation, and be underway to a new future of peace and cooperation.

\section{Conclusion}

Conflict over identity is what fueled ethnic conflict in South Africa and Northern Ireland, and the fact that these identities persist means that there is still the potential for a resurgence of violence

\footnotetext{
80 “Massive Van Bomb 'Ready to Go' at Northern Ireland Border.” The Independent. 28 April 2012.

81 Ibid.

82 “Eugene Terreblanche Murder: South African Man Guilty,” BBC News Africa, 22 May 2012
} 
between these groups. Ethnic violence has subsided, but the lingering tensions and identity politics continue to keep conflict alive. The answer to the amelioration of lingering ethnic problems in Northern Ireland and South Africa cannot be appropriately summarized in a single paper; in both cases centuries of mistrust and legitimate grievances on different sides weave a complex web of issues that must be tackled. No theory will be able to be perfectly applied, nor will a series of recommendations be able to be fully implemented with $100 \%$ success. The theories addressed, the plans outlined, and the suggestions made for implementing them are a series of hypotheses that represent only what is ideal, the optimum solution for a perfect world. Encouraging a culture and its leaders to change so drastically and in the manner prescribed is a tall order. But one thing is certain: the answer to the conflicts of Northern Ireland and South Africa lies in the people of these states, Protestant and Catholic, white, black, and coloured, and in the notion that the promises of peace will one day outweigh the cravings for vengeance and victory. It is therefore hoped that the recommendations outlined here will provide the makings of framework in which to do so, and serve as illuminating signposts on the path to an end to the conflict. 


\section{Bibliography}

Alan Aughey. The Politics of Northern Ireland: Beyond the Belfast Agreement. (2nd ed.) (London, England: Routledge. 2005). pp. 7-8

Agreement Reached in the Multi-Party Negotiations, 10 April 1998

Donald Akenson, “The High Noon of Apartheid, 1948-1969,” in God's Peoples: Covenant and Land in South Africa, Israel and Ulster. (Ithaca, New York: Cornell University Press. 1992) p. 205

George Bennett. “The Concept of Empire, Burke to Attlee, 1774-1947,” quoted in British

Imperialism: Gold, God, Glory ed. Robin Winks. (New York: Holt, Rinehart and Winston. 1963) p. 75

J.C. Beckett(1966) The Making of Modern Ireland 1603-1923. (London, England: Faber and Faber.1966) p. 461

Victor Bérard. British Imperialism and Commercial Supremacy. (New York: H. Fertig. 1973). pp. 47-48.

Steve Biko. “The Definition of Black Consciousness” in I Write What I Like. (London: Bowerdean Press. 1978). pp.48-49

Steve Biko. “The Righteousness of Our Strength” in I Write What I Like. (London: Bowerdean Press. 1978). p. 123

Michael Brown, “The Causes of Internal Conflict,” in M. Brown (Ed.), Nationalism and Ethnic Conflict. (Cambridge, Massachusetts: MIT Press. 1997) pp. 444-484

Roger Brubaker and David Laitin, “Ethnic and Nationalist Violence.” Annual Review of Sociology 4: 423-452. 1998

“Building Apartheid’s Pillars,” The Christian Science Monitor, 11 June 1986

Gregory Castle. Modernism and the Celtic Revival. (Cambridge: Cambridge University Press, 2001.) p. 239

John Cell. The Highest Stage of White Supremacy: The Origins of Segregation in South Africa and the American South. (Cambridge: Cambridge University Press, 1982). p. 51

Nancy L. Clark and William H. Worger, South Africa: The Rise and Fall of Apartheid, second ed. (Harlow, United Kingdom: Longman. 2011) p. 14 
Clifton Crais, White Supremacy and Black Resistance in Pre-Industrial South Africa: The Making of the Colonial Order in the Eastern Cape, 1770-1865. (Cambridge: Cambridge University Press, 1992). p. 128

A. A. B. Barrows D'Sa. "Twenty Five Years of Vascular Trauma in Northern Ireland.” (British Medical Journal, Volume 310, Issue 1. 1995)

"Eugene Terreblanche Murder: South African Man Guilty,” BBC News Africa, 22 May 2012 John Hobson. Imperialism. (London: G. Allen \& Unwin Ltd. 1938). p. 27

John Hobson. Imperialism. (London: G. Allen \& Unwin Ltd. 1938). p. 27

Colin Knox and Rachel Monaghan, Informal Justice in Divided Societies, (New York: Palgrave Macmillian. 2002). p.4

Chaim Kaufman. "Possible and Impossible Solutions to Ethnic Conflict.” In M. Brown (Ed.), Nationalism and Ethnic Conflict. (Cambridge, Massachusetts: MIT Press. 1997) p. 458

Stuart Kaufman. "Escaping the Symbolic Politics Trap: Reconciliation Initiatives and Conflict Resolution in Ethnic Wars.” (Journal of Peace Research, Volume 43 Issue 2. 2006). pp. 201-218.

Stuart Kaufman. "Symbolic Politics or Rational Choice? Testing Theories of Extreme Ethnic Violence.” (International Security, Volume 30 Issue 4. 2006). p. 48.

Brian Jenkins. Irish Nationalism and the British State: From Repeal to Revolutionary Nationalism. (Quebec: McGill-Queen’s University Press. 2006). pp. 49-50

N. G. Jesse \& K.P Williams. Ethnic Conflict: A Systematic Approach to Cases of Conflict. (Washington, DC: CQ Press. 2011) p. 98

“Malema Charged Over 'Kill the Boer'”, news24, 10 March 2010

Christoph Marx. “The Ossewabrandwag As a Mass Movement, 1939-1941” in Journal of Southern African Studies , Vol. 20, No. 2 (Jun., 1994), pp. 195-197

Seamus MacManus. The Story of the Irish Race: A Popular History of Ireland(4th rev. ed.). (New York: Devin-Adair Co. 1944.)

“Massive Van Bomb 'Ready to Go' at Northern Ireland Border.” The Independent. 28 April 2012.

John Stewart Mill, “A President in Council the Best Government for India” in The Collected Works of John Stuart Mill, XXX - Writings on India, ed. John M. Robson, Martin Moir, and Zawahir Moir (Toronto: University of Toronto Press, London: Routledge and Kegan Paul, 1990). 
William Minter, King Solomon's Mines Revisited: Western Interests and the Burdened History of Southern Africa. (New York: Basic Books. 1988). pp. 37-38

John Mueller. The Banality of Ethnic Conflict. (International Security, Volume 25 Issue 1. 2005).p. 45.

Vuyisile Msila, "From Apartheid Education to the Revised National Curriculum Statement: Pedagogy for Identity Formation and Nation Building in South Africa” in Nordic Journal of African Studies 16(2): 146-160 (2007).

“Northern Ireland Reconciliation Plan Arouses Anger.” The New York Times. 28 January 2009.

Alan O’Day. Reactions to Irish Nationalism. (London: Hambledon Press, 1987). p 19.

Ike Rosamarin and Dee Rissik. South Africa. 2nd ed. (New York: Benchmark Books, 2003). p 59.

Paul Rich, "Social Darwinism, Anthropology and English Perspectives of the Irish, 1867-1900," in History of European Ideas. (Volume 9, Issues 4-6. 1994). p. 777.

John Clark Ridpath and Edward Sylvester Ellis. The Story of South Africa: An Account of the Historical Transformation of the Dark Continent by the European Powers and the Culminating Contest Between Great Britain and the South African Republic in the Transvaal War. (Chicago: C.W. Stanton Co., 1899). p. 62

Martin Schönteich and Henry Boshoff, "'Volk' Faith and Fatherland. The Security Threat Posed by the White Right", in Monograph. (Institute of Security Studies No. 81. 2003) pp.13-14

“Self-imposed Apartheid.” The Guardian, 22 July 2007.

Peter Spiro, “Better Now Than Never: Economic and Social Reforms In South Africa’ in Cato Policy Analysis No. 81(Washington D.C.: Cato Institute. 1987).

“Tensions Rise at Terreblanche Hearing,” ReutersVideo, 6 April 2010

Leonard Thompson. The Political Mythology of Apartheid. (New Haven: Yale University Press, 1985). p. 26

Charles Tilly, The Politics of Collective Violence, (New York: Colombia University Press. 2003). p. 112

The Treaty of Limerick, 1691

Truth and Reconciliation Commission of South Africa Report, Volume 1 
David A. Valone and Jill Marie Bradbury. Anglo-Irish Identities 1571-1845. (Lewisburg: Bucknell University Press. 2008). p. 39.

Nahla Valji. Creating the Nation: The Rise of Violent Xenophobia in the New South Africa Unpublished Masters Thesis:York University, July 2003, Centre for the Study of Violence and Reconciliation.

“Violence Gnaws at South Africa’s Security Blanket,” Weekly Mail and Guardian, 22 March 2001

Daniel Wigmore-Shepherd, "Ethnic Identity, Political Identity and Ethnic Conflict: Simulating the Effect of Congruence Between the Two Identities on Ethnic Violence and Conflict," in Structure and Dynamics: eJournal of Anthropological and Related Sciences, 5(3). (2012): 4

Sue Williamson, Resistance Art in South Africa (Cape Town: David Phillip Publishers, 1989). p. 70

Robin Winks. British Imperialism: Gold, God, Glory. (New York: Holt, Rinehart and Winston. 1963). pp 2-3.

William Worger and Rita Burms. South Africa : A Country Study (Washington DC: Federal Research Division, Library of Congress. 1996). p. 1 